\title{
Burnout and depressive symptoms in intensive care nurses: relationship analysis
}

\author{
Burnout e sintomatologia depressiva em enfermeiros de terapia intensiva: análise de relação \\ Burnout y sintomatología depresiva en enfermeros de terapia intensiva: análisis de relación
}

\section{Eduardo Motta de Vasconcelos', Milva Maria Figueiredo De Martino', Salomão Patrício de Souza França" \\ ' Universidade Federal de São Paulo, Postgraduate Program in Nursing. São Paulo, Brazil. \\ "Universidade do Porto, Faculty of Psychology and Educational Sciences. Porto, Portugal.}

How to cite this article:

Vasconcelos EM, De Martino MMF, França SPS. Burnout and depressive symptoms in intensive care nurses: relationship analysis. Rev Bras Enferm [Internet]. 2018;71(1):135-41. DOI: http://dx.doi.org/10.1590/0034-7167-2016-0019

\begin{abstract}
Objective: To analyze the existence of a relationship between burnout and depressive symptoms among intensive care unit nursing staff. Method: A quantitative, descriptive, cross-sectional study with 91 intensive care nurses. Data collection used a sociodemographic questionnaire, the Maslach Burnout Inventory - Human Services Survey, and the Beck Depression Inventory - I. The Pearson test verified the correlation between the burnout dimension score and the total score from the Beck Depression Inventory. Fisher's exact test was used to analyze whether there is an association between the diseases. Results: Burnout was presented by $14.29 \%$ of the nurses and $10.98 \%$ had symptoms of depression. The higher the level of emotional exhaustion and depersonalization, and the lower professional accomplishment, the greater the depressive symptoms. The association was significant between burnout and depressive symptoms. Conclusion: Nurses with burnout have a greater possibility of triggering depressive symptoms.
\end{abstract}

Descriptors: Nurses; Intensive Care Units; Nursing Research; Psychological stress; Professional Exhaustion.

\section{RESUMO}

Objetivo: Analisar a existência de relação entre o burnout e a sintomatologia depressiva em enfermeiros de unidade de terapia intensiva. Método: Estudo quantitativo, descritivo, transversal, com 91 enfermeiros de terapia intensiva. Utilizouse, na coleta dos dados, um questionário sociodemográfico, o Maslach Burnout Inventory - Human Services Survey, e o Inventário de Depressão de Beck - versão I. O teste de Pearson verificou a correlação entre o escore das dimensões do burnout e o escore total do Inventário de Beck. O teste Exato de Fisher foi utilizado para analisar se existe associação entre as doenças. Resultados: Apresentaram burnout 14,29\% dos enfermeiros e 10,98\% tinham sintomas de depressão. Quanto maior o nível de exaustão emocional e despersonalização, e menor a realização profissional, maior foi a sintomatologia depressiva. A associação foi significativa entre o burnout e a sintomatologia depressiva. Conclusão: Os enfermeiros com burnout têm uma possibilidade maior de desencadear a sintomatologia depressiva.

Descritores: Enfermeiras e Enfermeiros; Unidades de Terapia Intensiva; Pesquisa em Enfermagem; Estresse Psicológico; Esgotamento Profissional.

\section{RESUMEN}

Objetivo: Analizar la existencia de relación entre burnout y la sintomatología depresiva en enfermeros de unidad de terapia intensiva. Método: Estudio cuantitativo, descriptivo, transversal, con 91 enfermeros de terapia intensiva. Se utilizó, en la colecta de datos, un cuestionario socio demográfico, el Maslach Burnout Inventory - Human Services Survey, y el Inventario de Depresión de Beck - versión I. El test de Pearson verificó la correlación entre la puntuación de las dimensiones de burnout e la puntuación total del Inventario de Beck. El test Exacto de Fisher fue utilizado para analizar si existe asociación entre las enfermedades. Resultados: Presentaron burnout 14,29\% de los enfermeros y 10,98\% tenían síntomas de depresión. Cuanto mayor el nivel de agotamiento emocional y despersonalización, y menor la realización profesional, mayor la sintomatología 
depresiva. La asociación fue significativa entre burnout y la sintomatología depresiva. Conclusión: Los enfermeros con burnout tienen una posibilidad mayor de desencadenar la sintomatología depresiva.

Descriptores: Enfermeras y Enfermeros; Unidades de Terapia Intensiva; Pesquisa en Enfermería; Estrés Psicológico; Agotamiento Profesional.

\section{CORRESPONDING AUTHOR Eduardo Motta de Vasconcelos E-mail: vasconcelos.motta@unifesp.br}

\section{INTRODUCTION}

Intensive care unit nurses are continuously influenced by various causes of stress in the work environment, such as: fatiguing workload, reduced staffing, and complexity of procedures. Due to the exhaustive and stressful work, these professionals are more likely to develop occupational stress, which is an important determinant of depression and burnout ${ }^{(1)}$.

When work-related stress transcends adaptive levels without an effective coping mechanism, it is called burnout or burnout syndrome. This is a predominant disease in professions that deal with people and arises as a consequence of interpersonal and organizational relations ${ }^{(1)}$. The term "burnout" means "to be consumed". This is a term that designates an individual who has reached collapsing point in his or her adaptive capacity ${ }^{(2)}$.

Depression is defined as a state of psychological suffering, which has repercussions on interpersonal relationships. It is characterized by the presence of negative thoughts, need for isolation, despondency, sadness, fatigue, insomnia, difficulties in concentration, anxiety, considerable fear, feelings of guilt, as well as alterations in sleep and appetite ${ }^{(3)}$.

It is recognized that the prevalence of intensive care unit nurses with burnout syndrome is high, and there is a significant association with depressive symptoms ${ }^{(4-5)}$.

Burnout is a distinct nosological entity that is often diagnosed as depression, leading to inappropriate treatment and consequent worsening of the clinical picture ${ }^{(4)}$. These are diseases with different dimensions and pathophysiology, i.e., depression has a pathophysiology related to an intrinsic trauma, while burnout is related to the workplace ${ }^{(5)}$.

The need for this study is justified by the importance of analyzing the relationship between burnout and depressive symptoms, since the results found may support the development of relevant points of reflection and the elaboration of occupational health programs in the institution, where this research was performed, in order to prevent and detect these diseases in intensive care unit nurses.

The aim of this study was to analyze the existence of a relationship between burnout and depressive symptoms in intensive care unit nurses.

\section{METHOD}

\section{Ethical aspects}

After the hospital's authorization, the project was submitted for evaluation by the Research Ethics Committee (CEP), and it was approved. The nurses were contacted and provided an explanation of the study. After agreeing to participate, they signed the Informed Consent Term. The research methods complied with the ethical precepts of Resolution 466/2012 of the National Health Council, which regulates research on human beings in Brazil(6).

\section{Design, place of study and period}

This is a quantitative, descriptive, cross-sectional study conducted at a university hospital in the city of São Paulo (SP), Brazil. The sample was defined using non-probabilistic convenience sampling. The subjects were selected according to their presence during the data collected period. There were a total of 130 intensive care nurses, of which 91 were selected to participate in the study. The inclusion criteria were: to be an assistant nurse working in an intensive care unit. The exclusion criteria were: on medical leave, maternity leave and on vacation, or if they declined to participate to participate in the study. In compliance with these criteria were excluded: 11 who were on holiday; three on medical leave, two on maternity leave; and 23 who were invited but refused to participate.

Nursing assistants worked in the various intensive care units: general, health plan, neurosurgery, pulmonology, pediatrics, neonatal, cardiac surgery, hemodialysis, cardiac, medical clinic, emergency room and burns.

\section{Population or sample; inclusion and exclusion criteria}

Data collection was done by the researcher responsible in July 2014, during the participants' working hours. In order to maintain confidentiality and privacy of the nurses, the instruments were completed in the Nursing comfort room or in a reserved room in the sector of practice and without the presence of other professionals. The instruments used were: a sociodemographic data collection form, the Maslach Burnout Inventory (MBI) Human Services Survey (HSS) and the Beck Depression Inventory (BDI) version I.

\section{Study protocol}

The sociodemographic data collection form consists of multiple-choice and open-ended questions, covering: gender, age, work sector, marital status, number of children, work shift, income, workload, ICU working time, number of patients attended per day and participation in in-service training.

The MBI-HSS for health professionals, translated and adapted by Benevides-Pereira, was used to identify the percentage of employees with burnout syndrome ${ }^{(7)}$.

The reference values of the Group of Studies and Research on Stress and Burnout Syndrome were used as cutoff points: emotional exhaustion (low - 0 to 15 , moderate -16 to 25 , and high 26 to 54); depersonalization (low - 0 to 2; moderate -3 to 8 ; and high - 9 to 30); and professional accomplishment (low - 0 to 33, moderate -34 to 42 , and high -43 to 48$)^{(7)}$. Burnout syndrome is characterized by the combination of high emotional exhaustion, high depersonalization and low professional accomplishment ${ }^{(8)}$. 
The BDI was also applied, in order to determine the percentage of nurses with depressive symptoms. The version used was BDI-I, validated for Brazil, with 21 questions assessing the presence of depressive symptoms in relation to the week prior to application of the instrument ${ }^{(9)}$. The cut-off points were those recommended for undiagnosed samples: scores above 15 indicate dysphoria, and above 20 indicate depression ${ }^{(10)}$.

\section{Analysis of results and statistics}

The results were expressed using descriptive statistics: mean, standard deviation and percentages for the categorical variables. The inferential statistical techniques used were Pearson correlation test and Fisher's exact test. Using the Pearson test, it was possible to verify the correlation between MBI-HSS dimensions and the total BDI-I score. To verify the association between individuals with burnout syndrome and symptoms of depression, Fisher's exact test was applied; the strength of association between the variables was evaluated through the Odds Ratio (OR) with Confidence Interval $(\mathrm{Cl})$.

The margin of error adopted in the decisions of the statistical tests was $5 \%(p<0.05)$ and with $95 \%$ confidence intervals. Statistical analyses were performed using the Statistical Package for the Social Sciences, version 21.

\section{RESULTS}

In compliance with the inclusion criteria, the study sample comprised a total of 91 care nurses. Of these, $81(89.0 \%)$ were women, $57(62.6 \%)$ were single and $34(37.4 \%)$ were married. The mean age presented was 30.82 years, with a standard deviation of 6.42 . As to the number of children, $65(71.4 \%)$ reported not having children, that is, it was a young population, and most had no children.

The nurses were predominantly public-sector employees $78(85.7 \%)$. Regarding the shift, $31(34.0 \%)$ worked at night. Only six $(6.6 \%)$ had a second job and $42(46.2 \%)$ had an income of 2 to 5 minimum wages.

As to the work sectors, the distribution of nurses in the various ICUs was: 17 (18.6\%) general intensive care unit; 10 (11.0\%) health plan; eight (8.8\%) neurosurgery; six (5.5\%) pediatric; 10 $(11.0 \%)$ neonatal; five $(5.5 \%)$ cardiac surgery; seven $(7.7 \%)$ hemodialysis; seven $(7.7 \%)$ cardiac; six $(6.6 \%)$ medical clinic; five (5.5\%) emergency room; and five (5.5\%) burns.

According to $\mathrm{MBI}$ results, of the 91 nurses interviewed, 78 $(85.7 \%)$ did not present burnout syndrome against $13(14.3 \%)$ with burnout.

From BDI, 81 (89.0\%) had no depressive symptoms, five $(5.5 \%)$ had symptoms of dysphoria and five $(5.5 \%)$ had depressive symptoms, that is $11.0 \%$ presented symptoms of depression. Table 1 shows the profile of nurses with burnout and symptoms of depression.

Table 2 presents the correlation between the burnout dimension scores and total DBI score (depressive symptoms) using Pearson's $r$ test. It was observed that there was a moderate positive correlation between emotional exhaustion and total BDI score $(r=0.5852 ; p<0.001)$, with a significantly stronger correlation level in this dimension. The correlation was moderately positive between the depersonalization dimension and the total BDI score $(r=0.4593, p<0.001)$. Between the professional accomplishment score and total BDI score there was a weak negative correlation $(r=-0.3741, p<0.001)$.

Table 3 shows that the percentage of participants classified as having high emotional exhaustion, high depersonalization and low professional accomplishment was higher among those with depressive symptoms $(80.0 \%$ high emotional exhaustion, 70\% high depersonalization and 70\% low professional accomplishment). According to Fisher's exact test, no significant association ( $p>0.05$ ) was found between the occurrence of depressive symptoms and the variables of emotional exhaustion $(p=0.064)$, depersonalization $(p=0.061)$ and professional accomplishment $(p=0.052)$.

Furthermore, in Table 3 the percentage of individuals with burnout was higher among those who presented depressive symptoms (40.0\%) against those who did not (11.1\%). According to the Fisher's exact test, the occurrence of burnout syndrome was the only variable with significant association $(p=$ $0.033, \mathrm{OR}=5.33$ and interval excluding the value of 1.00).

Table 1 - Distribution of sociodemographic variables in nurses with burnout and symptoms of depression, São Paulo, Brazil, 2014

\begin{tabular}{|c|c|c|c|c|c|c|}
\hline \multirow{2}{*}{ Variable } & \multicolumn{3}{|c|}{ Nurses with burnout } & \multicolumn{3}{|c|}{ Nurses with depressive symptoms } \\
\hline & Mean & Category & n (\%) & Mean & Category & n (\%) \\
\hline Age (years) & 27.85 & - & - & 26.88 & - & - \\
\hline Work sector & - & Neonata $V$ Emergency & $3 / 3(23.1 / 23.1)$ & - & General & $4(40)$ \\
\hline Gender & - & Female & $13(100)$ & - & Female & $9(90)$ \\
\hline Marital status & - & Single & $10(76.9)$ & - & Single & $8(80)$ \\
\hline Number of children & - & None & $11(84.6)$ & - & None & $9(90)$ \\
\hline Work shift & - & Morning/Night & $5 \sqrt{5}(38.5 \sqrt{38.5)}$ & - & Afternoon $\sqrt{ }$ ight & $4 / 4(40 / 40)$ \\
\hline Income (min. salaries) & - & 6 to 9 & $5(38.5)$ & - & 2 to 5 & $5(50)$ \\
\hline Workload (hours) & - & 30 to 40 & $7(53.7)$ & - & Over $60 \mathrm{~h}$ & $3(30)$ \\
\hline ICU work time (months) & - & 25 to 36 & $4(30.8)$ & - & 6 to 12 & $4(40)$ \\
\hline Patients attended (per day) & - & Less than 10 & $10(76.9)$ & - & More than 10 & $9(90)$ \\
\hline Attended in-service training & - & No & $7(53.7)$ & - & Yes & $6(60)$ \\
\hline
\end{tabular}

Note: ICU: Intensive Care Unit 
Table 2 - Correlation between Maslach Burnout Inventory (MBI) and Beck Depression Inventory (BDI), São Paulo, Brazil, 2014

\begin{tabular}{lcc} 
Statistical test & $\mathbf{r}$ & $\boldsymbol{p}$ value \\
\hline Emotional Exhaustion Score $\times$ Beck Depression Inventory Overall Score & 0.5852 & $p^{(1)}<\mathbf{0 . 0 0 1}$ \\
Depersonalization Score $\times$ Beck Depression Inventory Overall Score & 0.4593 & $p^{(1)}<\mathbf{0 . 0 0 1}$ \\
Professional Accomplishment Score $\times$ Beck Depression Inventory Overall Score & -0.3741 & $p^{(1)}<\mathbf{0 . 0 0 1}$
\end{tabular}

Note: $r$ : correlation coefficient; ${ }^{(1)}$ : using Pearson's correlation test.

Table 3 - Correlation between Maslach Burnout Inventory (MBI) and Beck Depression Inventory (BDI), São Paulo, Brazil, 2014

\begin{tabular}{|c|c|c|c|c|c|c|c|c|}
\hline \multirow{3}{*}{ Variable } & \multicolumn{4}{|c|}{ Depression } & \multirow{2}{*}{\multicolumn{2}{|c|}{ Total }} & \multirow{3}{*}{$p$ value } & \multirow{3}{*}{ OR (Cl 95) } \\
\hline & \multicolumn{2}{|c|}{ Present } & \multicolumn{2}{|c|}{ Absent } & & & & \\
\hline & $\mathbf{n}$ & $\%$ & $\mathbf{n}$ & $\%$ & $\mathbf{n}$ & $\%$ & & \\
\hline Group total & 10 & 11.0 & 81 & 89.0 & 91 & 100.0 & & \\
\hline \multicolumn{9}{|c|}{ Emotional exhaustion } \\
\hline High & 8 & 80.0 & 35 & 43.2 & 43 & 47.0 & $p^{(1)}=0.064$ & $* *$ \\
\hline Average & 2 & 20.0 & 29 & 35.8 & 31 & 34.0 & & $* *$ \\
\hline Low & - & - & 17 & 21.0 & 17 & 19.0 & & $* *$ \\
\hline \multicolumn{9}{|c|}{ Depersonalization } \\
\hline High & 7 & 70.0 & 24 & 29.6 & 31 & 34.0 & $p^{(1)}=0.061$ & $* *$ \\
\hline Average & 2 & 20.0 & 33 & 40.7 & 35 & 38.0 & & $* *$ \\
\hline Low & 1 & 10.0 & 24 & 29.6 & 25 & 27.0 & & $* *$ \\
\hline \multicolumn{9}{|c|}{ Professional accomplishment } \\
\hline High & 1 & 10.0 & 18 & 22.2 & 19 & 21.0 & $p^{(1)}=0.052$ & $* *$ \\
\hline Average & 2 & 20.0 & 39 & 48.1 & 41 & 45.0 & & $* *$ \\
\hline Low & 7 & 70.0 & 24 & 29.6 & 31 & 34.0 & & $* *$ \\
\hline \multicolumn{9}{|l|}{ Burnout } \\
\hline Present & 4 & 40.0 & 9 & 11.1 & 13 & 14.0 & $p^{(1)}=0.033^{*}$ & 5.33 (1.26 to 22.57$)$ \\
\hline Absent & 6 & 60.0 & 72 & 88.9 & 78 & 86.0 & & 1.00 \\
\hline
\end{tabular}

Note: OR: Odds Ratio; Cl: Confidence Interval; $\left({ }^{*}\right)$ : Significant association at 5.0 level; $(* *)$ : Not possible to determine due to zero or very low frequencies; ${ }^{(1)}$ : Using Fisher's exact test.

\section{DISCUSSION}

In nursing, burnout has been studied for several years because of its high prevalence and because it is recognized as an occupational risk ${ }^{(11)}$. In other studies that used MBI to identify burnout, a prevalence of $9.22 \%^{(2)}$ and $24 \%^{(12)}$ was observed. In the literature, the results found vary according to the method used. Nevertheless, the prevalence of this disease has been high in all the cited studies, corroborating the index found in the present work, which was $15.29 \%$.

Regarding the prevalence of depressive symptoms, the results found in the literature showed $9 \%$ with severe depression and $21 \%$ with dysphoria ${ }^{(13)}$. Our findings indicated percentages of $5.49 \%$ for both, somewhat lower than reported in the literature. It is believed that this occurred due to the singular characteristics of each sample; in this case, only nursing assistants participated.

Regarding the profile of nurses with burnout, there is a predominance of young individuals ${ }^{(14)}$, aged between 31 to 35 years, female, single and childless ${ }^{(15)}$. A contradictory result was found for the variable age in the literature ${ }^{(16)}$, but most studies report that burnout has a higher prevalence among younger nurses, since these are considered inexperienced and more likely to suffer anxiety when faced with eventual intercurrences during their shift ${ }^{(17-18)}$.

A study carried out in Mato Grosso, in the Center-West of Brazil, with nursing workers, showed that $7.09 \%$ of the sample presented burnout and less than 5 years of working in the unit, that is, they had little professional experience in the ICU ${ }^{(2)}$. This confirms the prevalence of burnout is higher in young, inexperienced nurses working with patients of high complexity; in addition, these individuals have common characteristics of susceptibility.

Regarding the work shift, the prevalence of burnout syndrome is generally considered to be higher in nurses working at night; in the present study however, a contradictory finding showed an equal percentage between the morning and night shifts ${ }^{(13,15)}$.

The literature points out that the professionals most affected by burnout are those with over 30 hours of service per week, since professionals with a shorter workload often choose to have a second job because they see this as a possibility of improving their income ${ }^{(2)}$.

Regarding the number of patients attended per day, the majority of subjects with burnout attended fewer than 10 patients. According to a study carried out with intensive care unit nurses at a university hospital, interpersonal relationships were identified as one of the main factors that cause burnout syndrome ${ }^{(19)}$. The ICU nurse attends an overly large number of highly complex patients on a daily basis, which is often the result of insufficient numbers of staff. The excess of tasks per staff member demands an accelerated rhythm when performing the activities and less time to rest, plus an increase in the quantity of interpersonal relations. This combination predisposes these professionals to stress-related disease $\mathrm{e}^{(20)}$.

Regarding the profile of nursing workers with depressive symptoms, there is predominance among females and young people between 20 and 40 years of age ${ }^{(21)}$. However, another national study reported that the age variable was not significantly associated with increased prevalence of depressive symptoms ${ }^{(13)}$.

As for marital status, there is a higher prevalence of depression in people who do not have close interpersonal relationships, without children, or who are separated or divorced ${ }^{(13)}$.

Studies carried out with nursing staff working in an intensive care unit showed that the prevalence of depressive symptoms is higher in professionals working in the night shift and that there was a significant association between depressive symptoms and work shift ${ }^{(13,22-24)}$, a contradictory result to this 
research. The literature points out that the probability of these night shift workers presenting depressive symptoms was 1.48 (OR) times the chance of day shift professionals ${ }^{(13)}$.

Night work is detrimental to health due to changes in the circadian rhythm, which are associated with the exhausting characteristics of the intensive care unit environment, heightening their effects on the mental health of nursing workers. The greater the number and length of night shifts, the greater the prevalence of psychiatric illness ${ }^{(5,13)}$.

Regarding the prevalence of depressive symptoms in nurses according to the type of intensive care unit, the literature shows that there was no significant difference between the percentages found between the units. However, a higher prevalence of depressive symptoms was observed in the intensive care unit nursing team at a private hospital, probably due to the pressure exerted and higher demands in these institutions, contributing to the onset of depressive disorders ${ }^{(13)}$.

With regard to income, a study carried out with nurses from a university hospital in Estonia, confirmed that there is a significant association with depressive symptoms and burnout $^{(25)}$. From the results in Table 1 , it is emphasized that the majority of individuals with depressive symptoms had a low income, while those with burnout had a higher income. Corroborating these results, the literature points out that the lower the income, the greater the chance of presenting depressive symptoms ${ }^{(26)}$; whereas the higher the income, the greater the chance of presenting burnout ${ }^{(27)}$.

As to the number of hours worked and the number of patients attended per day, the literature indicates that these are considered predictive factors for the development of depressive symptoms ${ }^{(14)}$. Among the nurses who presented depressive symptoms, the majority worked over 60 hours a week and attended more than 10 patients per day.

It is believed that burnout predicts depressive symptoms and not the opposite, since the latter may arise as a result of the syndrome ${ }^{(28-29)}$. This is a very controversial question for inexperienced researchers and has been discussed for many years ${ }^{(5)}$.

According to the results of Table 2, where the correlation between the burnout dimension scores and the total BDI score (depressive symptoms) was verified, it could be said that a correlation existed, in which, the higher the level of emotional exhaustion and depersonalization, the greater the depressive symptoms; And the lower the professional accomplishment (inversely proportional), the greater the depressive symptoms.

Studies show that professionals with increased burnout tend to have an increase in depressive symptoms ${ }^{(5,30)}$. Emotional exhaustion, considered the nucleus of burnout, showed a stronger correlation with depressive symptoms than depersonalization, which is considered the second dimension of burnout. The correlation of the professional achievement dimension was negative with depressive symptoms. This data corroborates the results found in the present study ${ }^{(5,29-32)}$.

The dimensions of burnout were not significantly associated with depressive symptoms (Table 3). However, in a larger sample, if the results maintained the same proportion, we would have a significant association $(p<0.05)$. This result was contradictory to that found in a study carried out in Portugal, where there was a significant association between the three dimensions of burnout and depressive symptoms ${ }^{(29)}$.

Table 3 shows a significant association between the presence of burnout and depressive symptoms ( $p=0.033$ ), in which the probability of the nurses with burnout presenting depressive symptoms is $5.33(\mathrm{OR})$ times the chance of the nurse without burnout. The literature confirms the result found, reporting a significant association between these two diseases ${ }^{(33)}$.

The prevalence rates of burnout syndrome $\mathrm{e}^{(2,12)}$ and depressive symptoms are alarming ${ }^{(13)}$. Through the authors' professional experience, it can be observed that the National Health Policy for Workers is far from fulfilling the needs of these professionals. It is essential that strategies for coping with burnout and depressive symptoms in the occupational field are adopted, as this may reflect on the quality of care provided, as well as on the rate of absenteeism.

\section{Limitations of the study and contributions to the health area}

The limitations of the study are related to the number of participants involved that did not allow generalization of the results. In addition, MBI-HSS and BDI do not have diagnostic power, that is, for the confirmation of burnout. An evaluation by an experienced psychiatrist is preferable, whereas, for confirmation of depression, the psychiatrist's evaluation should be based on the Diagnostic and Statistical Manual of Mental Disorders - Fifth Edition (DSM - 5) ${ }^{(3)}$.

\section{CONCLUSION}

There was a correlation in which, the higher the level of emotional exhaustion and depersonalization, the greater the depressive symptoms; and the lower the professional accomplishment (inversely proportional), the greater the depressive symptoms.

The percentage of individuals with burnout was higher in the group with depressive symptoms than in the group without the disease. There was a significant association between burnout syndrome and depressive symptoms in ICU nurses, that is, nurses with burnout have a greater possibility of triggering depressive symptoms than the group without the disease.

\section{ACKNOWLEDGEMENTS}

Coordenação de Aperfeiçoamento de Pessoal de Nível Superior (CAPES), for funding the study with a Master's degree grant [process number: 134249/2013-5].

\section{REFERENCES}

1. Khamisa N, Oldenburg B, Peltzer K, Ilic D. Work related stress, burnout, job satisfaction and general health of nurses. Int J Environ Res Public Health [Internet]. 2015[cited 2017 Feb 14];12(1):652-66. Available from: https://www.ncbi.nlm.nih.gov/pubmed/ 27241867 
2. França FM, Ferrari R, Ferrari DC, Alves ED. Burnout and labour aspects in the nursing teams at two medium-sized hospitals. Rev Latino-Am Enfermagem [Internet]. 2012 [cited 2017 Feb 14];20(5):961-70. Available from: http://www.scielo.br/pdf/rlae/ v20n5/19.pdf

3. American Psychiatric Association. DSM-5: manual diagnóstico e estatístico de transtornos mentais. 5. ed. Porto Alegre (RS): Artmed; 2014.

4. Ahola K, Hakanen J, Perhoniemi R, Mutanen P. Relationship between burnout and depressive symptoms: a study using the person-centred approach. Burn Res[Internet]. 2014[cited 2017 Feb 14];1(1):29-37. Available from: https://doi.org/10.1016/j. burn.2014.03.003

5. Papathanasiou IV. Work-related mental consequences: implications of burnout on mental health status among health care providers. Acta Inform Med [Internet]. 2015[cited 2017 Feb 14];23(1):22-8. Available from: https://www.ncbi.nlm.nih. gov/ pubmed/25870487

6. Brasil. Conselho Nacional de Saúde. Resolução nº. 466, de 12 de dezembro de 2012. Diretrizes e normas regulamentadoras de pesquisas envolvendo seres humanos[Internet]. Diário Oficial da União 13 de junho de 2013[cited 2017 Feb 14];Seção 1. Available from: http://conselho.saude.gov.br/resolucoes/2012/Reso466.pdf

7. Benevides-Pereira AMT. (Org.). Burnout: quando o trabalho ameaça o bem estar do trabalhador. $3^{\text {a }}$ ed. São Paulo: Casa do Psicólogo; 2010.

8. Maslach CP, Jackson SE. Maslach Burnout Inventory. 2nd ed. Palo Alto: Consulting Psychologist Press; 1986.

9. Andrade L, Gorenstein C, Vieira Filho AH, Tung TC, Artes R. Psychometric properties of the Portuguese version of the State-Trait Anxiety Inventory applied to college students: factor analysis and relation to the Beck Depression Inventory. Braz J Med Biol Res [Internet]. 2001[cited 2017 Feb 10];34(3):367-374. Available from: http://www.scielo.br/pdf/bjmbr/v34n3/3860m.pdf

10. Gorenstein C, Andrade L, Zuardi, AW, editores. Escalas de avaliação clínica em psiquiatria de psicofarmacologia. São Paulo: Lemos Editorial; 2000.

11. Ding Y, Yang Y, Yang X, Zhang T, Qiu X, He X, et al. The mediating role of coping style in the relationship between psychological capital and burnout among chinese nurses. PLoS One [Internet]. 2015[cited 2017 Feb 14];10(4):1-14. Available from: https:// www.ncbi.nlm.nih.gov/pubmed/25898257

12. Benitez M, Rodriguez E. Burnout's Syndrome in the nursing staff of intensive care in a hospital of Montevideo city. Enfermería (Montev.) [Internet]. 2014[cited 2017 Feb 14];3(1):21-7. Available from: http://ucu.edu.uy/sites/default/files/ publicaciones/2014/ revista_enfermeria_cuidados_humanizados_vol.3.1_jun2014.pdf

13. Vargas D, Dias APV. Depression prevalence in Intensive Care Unit nursing workers: a study at hospitals in a northwestern city of São Paulo State. Rev Latino-Am Enfermagem [Internet]. 2011[cited 2017 Feb 14];19(5):1114-21. Available from: http://www. scielo.br/pdf/rlae/v19n5/08.pdf

14. Muse S, Love M, Christensen K. Intensive OutPatient therapy for Clergy Burnout: how much difference can a week make? J Relig Health [Internet]. 2015[cited 2017 Feb 14];55(1):147-58. Available from: https://www.ncbi.nlm .nih.gov/pubmed/25682015

15. Ribeiro VF, Ferreira Filho C, Valenti VE, Ferreira M, Abreu LC, Carvalho TD et al. Prevalence of burnout syndrome in clinical nurses at a hospital of excellence. Int Arch Med [Internet]. 2014 May [cited 2017 Feb 14]; 7(22):1-7. Available from: https://www. ncbi.nlm.nih.gov/pmc/articles/PMC4031323/

16. França FM, Ferrari R. Burnout Syndrome and the socio-demographic aspects of nursing professionals. Acta Paul Enferm [Internet]. 2012 [cited 2017 Feb 14];25(5):743-8. Available from: http://www.scielo.br/pdf/ape/v25n5/en 15.pdf

17. França SPS, De Martino MMF, Aniceto EVS, Silva LL. Preditores da Síndrome de Burnout em enfermeiros de serviços de urgência pré-hospitalar. Acta Paul Enferm[Internet]. 2012[cited 2017 Feb 14];25(1):68-73. Available from: http://www.scielo.br/pdf/ape/ v25n1/en_v25n1a12.pdf

18. Poncet MC, Toullic P, Papazian L, Kentish-Barnes N, Timsit JF, Pochard F, et al. Burnout syndrome in critical care nursing staff. Am J Respir Crit Care Med [Internet]. 2007 [cited 2017 Feb 14];175(7):698-704. Available from: https://www.ncbi.nlm.nih.gov/ pubmed/17110646

19. Splawska K. Burnout symptoms of cardiosurgery nurses. Pol Merkur Lekarski [Internet]. 2013[cited 2017 Feb 14];35(206):94-9. Available from: https://www.ncbi.nlm.nih.gov/pubmed/?term = Burnout + symptoms + of + cardiosurgery + nurses

20. Mininel VA, Baptista PCP, Felli VEA. Psychic workloads and strain processes in nursing workers of Brazilian university hospital. Rev Latino-Am Enfermagem [Internet]. 2011 [cited 2017 Feb 14];19(2):340-7. Available from: http://www.scielo.br/pdf/rlae/ v19n2/16.pdf

21. Moreira DP, Furegato ARF. Stress and depression among students of the last semester in two nursing courses. Rev Latino-Am Enfermagem [Internet]. 2013[cited 2017 Feb 14];21(Spec-No):155-62. Available from: http://www.scielo.br/pdf/rlae/v21nspe/20.pdf

22. Vieira TG, Beck CLC, Dissen CM, Camponogara S, Gobatto M, Coelho APF. Adoecimento e uso de medicamentos psicoativos entre trabalhadores de enfermagem de unidades de terapia intensiva. Rev Enferm UFSM[Internet]. 2013 [cited 2017 Feb 14];3(2):20514. Available from: https://periodicos.ufsm.br/reufsm/article /view/7538

23. Øyane NMF, Pallesen S, Moen BE, Åkerstedt T, Bjorvatn B, Tranah G. Associations between night work and anxiety, depression, 
insomnia, sleepiness and fatigue in a sample of Norwegian nurses. PLoS One [Internet]. 2013[cited 2017 Feb 02];8(8):e70228. Available from: http://journals.plos.org/plosone/article?id=10.1371/journal.pone.0070228

24. Silva DSD, Tavares NVS, Alexandre ARG, Freitas DA, Brêda MZ, Albuquerque MCS et al. Depressão e risco de suicídio entre profissionais de Enfermagem: revisão integrativa. Rev Esc Enferm USP[Internet]. 2015[cited 2017 Feb 14];49(6):1027-36. Available from: https://www.revistas.usp.br/reeusp/article/view/108430

25. Freimann T, Merisalu E. Work-related psychosocial risk factors and mental health problems amongst nurses at a university hospital in Estonia: a cross-sectional study. Scand J Public Health [Internet]. 2015 [cited 2017 Feb 14];43(5):447-52. Available from: https:// www.ncbi.nlm.nih.gov/pubmed/25851017

26. Tegegne MT, Mossie TB, Awoke AA, Assaye AM, Gebrie BT, Eshetu DA. Depression and anxiety disorder among epileptic people at Amanuel Specialized Mental Hospital, Addis Ababa, Ethiopia. BMC Psychiatry [Internet]. 2015 [cited 2017 Feb 14];15:1-7. Available from: https://www.ncbi.nlm.nih.gov/pmc/articles/PMC4556015/

27. Qureshi HA, Rawlani R, loton LM, Dumanian GA, Kim JY, Rawlani V. Burnout phenomenon in U.S. plastic surgeons: risk factors and impact on quality of life. Plast Reconstr Surg [Internet]. 2015[cited 2017 Feb 14];135(2):619-26. Available from: https://www. ncbi.nlm.nih.gov/pubmed/25357156

28. Hakanen JJ, Schaufeli WB. Do burnout and work engagement predict depressive symptoms and life satisfaction? a three-wave seven-year prospective study. J Affect Disord [Internet]. 2012 [cited 2017 Feb 14];141(2-3):415-24. Available from: https:// www. ncbi.nlm.nih.gov/pubmed/22445702

29. Murcho NAC, Jesus SN, Pacheco JEP. A relação entre a depressão em context laboral e o burnout: um estudo empírico com enfermeiros. Psicol Saúde Doenças [Internet]. 2009; [cited 2017 Feb 14];10(1):57-68. Available from: http://www.redalyc. org/ pdf/362/36219059005.pdf

30. Bianchi R, Schonfeld IS, Laurent E. Is burnout separable from depression in cluster analysis? a longitudinal study. Soc Psychiatry Psychiatr Epidemiol [Internet]. 2015 [cited 2017 Feb 14];50(6):1005-11. Available from: https://www.ncbi.nlm.nih.gov/pubmed/ 25527209

31. Bianchi R, Boffy C, Hingray C, Truchot D, Laurent E. Comparative symptomatology of burnout and depression. J Health Psychol [Internet]. 2013 [cited 2017 Feb 14];18(6):782-87. Available from: http://journals.sagepub.com/doi/abs/10.1177/1359 105313481079

32. Bianchi R, Schonfeld IS, Laurent E. Burnout-depression overlap: A review. Clin Psychol Rev [Internet]. 2015 [cited 2017 Feb 14$]$; 36:28-41. Available from: https://www.ncbi.nlm.nih.gov/pubmed/25638755

33. Galán F, Ríos-Santos JV, Juan Polo, Rios-Carrasco B, Bullón P. Burnout, depression and suicidal ideation in dental students. Med Oral Patol Oral Cir Bucal [Internet]. 2014 [cited 2017 Feb 14]; 19(3):206-11. Available from: https://www. ncbi.nlm.nih.gov/ pubmed/24121916 